\title{
Gawad Plaridel Lecture 2017
}

Tina Monzon Palma

On 23 August 2017, the Gawad Plaridel, the highest award given by the University of the Philippines (U.P.) to outstanding media practitioners, was conferred by U.P. President Danilo Concepcion in the presence of U.P. Diliman Chancellor Michael L. Tan, U.P. College of Mass Communication (CMC) Dean Elena Pernia and CMC Broadcast Communication Chair Eulalio III Guieb on Ms. Chrisina Monzon-Palma.

The U.P. Gawad Plaridel 2017 was awarded toPalma for her pioneering role as a woman news broadcaster that set a high standard in broadcast journalism in the country. Her dedication and integrity challenged state power and the control of media during the Marcos dictatorship. Tina Monzon Palma took the lead role as news anchor and news director in three stations at a time when women were relegated in the margins of news reporting, a feat that has enabled the younger generation to assume news management positions that allow them to affect the quality of broadcast journalism and negotiate and even defy the intensifying commercialization of television. Her uncompromising and unwavering integrity in her profesional life seves as a model worth emulating by next generations of broadcast journalists.

This issue of Plaridel publishes three documents relevant to the proclamation of Ms. Palma as 2017 Gawad Plaridel awardee: first, the official citation which enumerates and describes the achievements for which Ms. Palma is being recognized; second, an essay on the life and works of the awardee by Luz Rimban; and third, the Gawad Plaridel speech of the awardee. 


\section{The Gawad Plaridel 2017 Citation for Ms. Tina Monzon Palma}

For her pioneering role as a woman news broadcaster that set a high standard in broadcast journalism in the country;

For uncompromisingly standing by her professional decisions and ethical standards even as these challenged state power and the control of media during the Marcos dictatorship and beyond;

For taking on the lead role as news anchor and news director in three television stations at a time when women were relegated in the margins of news reporting and for bearing witness to the growth of broadcast journalism in the country;

For opening doors for women broadcast journalists to take on lead roles as news anchors, news directors, and television executives;

For mentoring younger generations of broadcast journalists in the country, enabling them to diversify news programming and to assume news management positions that allow them to affect the quality of broadcast journalism and negotiate and even defy the intensifying commercialism of television;

For her uncompromising and unwavering integrity that sought to implement the highest ethical standards in her more than 40 years of service in broadcast journalism, an exemplary professional life that has served as a model for the next generations of broadcast journalists; 
The UP College of Mass Communication awards the U.P. Gawad Plaridel to Ma. Christina Monzon Palma this 23rd day of August in the year 2017 at the Cine Adarna, UPFI Film Center, University of the Philippines, Diliman, Quezon City.

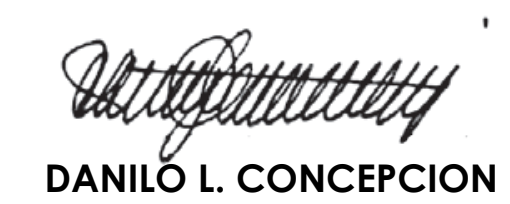

President, University of the Philippines

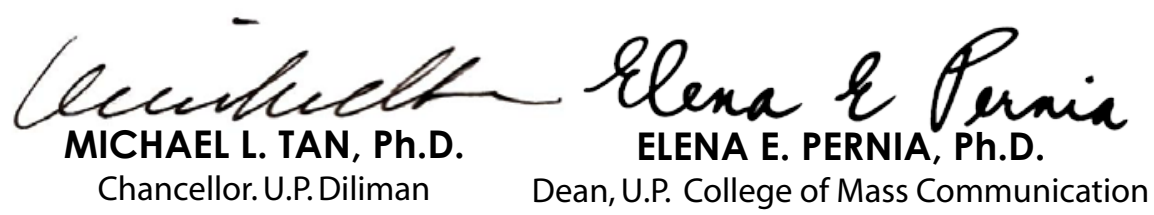




\section{The Prime of Ms. Tina Monzon Palma}

Luz Rimban

It was the ringing of the telephone that awakened me at around 1:00 a.m. of Friday, December 1, 1989. My boss, Tina Monzon Palma, was calling.

"Come to work. There's a coup," she said and hung up. No hello, no goodbye, no further instructions. I was then a television reporter for GMA-7, and I did as I was told, no questions asked.

Minutes later, I was at the GMA-7 newsroom which was then just a bungalow in the network's compound on EDSA in Quezon City. A small group had gathered, composed mostly of those whom Tina could reach by landline, since mobile phones did not yet exist and some of the

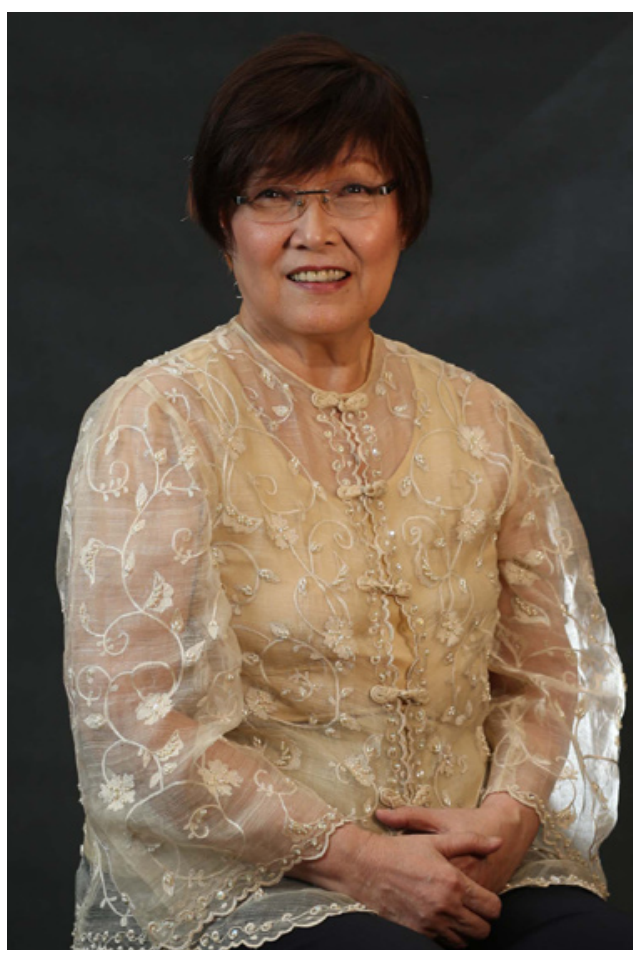
staff's walkie-talkie units were turned off and being charged for the night.

She gave senior reporter Jimmy Gil and myself keys to the news vehicles and asked us to drive them out of the compound to safety, in case the station was attacked. And then we were back at the newsroom, listening to her telling us how we were going to cover the story.

The story was the attempt by rebel soldiers to seize power in December 1989, the bloodiest challenge to the leadership of Corazon Aquino, the country's first female president. That coup tested Tina's capabilities as well. TMP, as she was addressed, was then 39 years old and senior vice president of GMA-7 News, the first female to hold that position and at that time the only woman at the helm of a national TV news division in the Philippines.

Tina's responsibility was to help secure the broadcast facilities of GMA-7 against a possible attack by rebel soldiers. But she also wanted to make sure the network stayed on the air to broadcast stories about the coup, to the consternation of Malacañang and military officials who chastised her for giving rebel soldiers precious airtime. 
Looking back to those days, she said she felt the public deserved to know who the government's enemy was, although government itself disagreed and its officials kept pestering her to cease broadcast. Tina remembers having the audacity to tell them, "You do your job, and I will do my job."

"I was reckless and fearless," she told a group of University of the Philippines professors in June 2017, "not because I was courageous or wanted to make a name for myself, but because nobody could really affect the way you do your job."

It didn't seem like it at that time but Tina Monzon Palma was making television history. She proved that a woman could lead a TV news department competently through the most difficult times and that she could engage the powers that be in a battle of wills over what could and could not be broadcast. She eventually backed down as national security concerns prevailed, but she was paving the way for more women to assert themselves in leadership roles in broadcast news in the years to come.

Tina Palma was born Ma. Cristina Mapa Monzon, the third of seven children of Andres Monzon, a government employee, and Priscilla Mapa, a housewife. She grew up in the company of boys - two older brothers and two younger ones-and was the only girl in the family until she was eight years old when her sister Ma. Estrella or Maritel was born, followed by another brother.

Her family called her Cristine, the no-fuss, no-frills girl who got along well with boys, Maritel Monzon Eusebio said. She abhorred make-up and fancy dresses, and preferred reading to attending parties. She was driven and hardworking, and a stickler for rules and discipline.

The Monzon family lived in Malate, and Tina spent her elementary and high school years at Malate Catholic School (MCS) under the tutelage of Columban nuns. She became one of the prodigies of Sister Mary Pius, the Irish nun who trained her to win declamation contests.

Tina was a campus celebrity-student council president, star athlete, champion declaimer, thespian, honor student-with fans of her own. "She was the idol of the students," Maritel remembers, and during intramurals, the crowd erupted in cheers every time her sister jumped and spiked the volleyball.

It was at MCS that Tina developed a love for the arts, said Inday RefiCascariño, her classmate from elementary to college. Inday was also a prodigy of Sister Mary Pius, and she and Tina shared a love for reading and Shakespeare.

Tall and often pixie-haired, Tina was usually cast as the leading man in stage plays, and cut a dashing figure playing Hamlet and Macbeth. Inday 
said the school even had her friend trained in fencing so she could play the Shakespearean characters more realistically.

After high school, Tina enrolled at St. Paul Manila hoping to go into Theater Arts. But after one semester, she found herself at St. Scholastica's College enrolled in AB Education with some of her other MCS friends.

During her freshman year, she responded to a call for auditions at radio station DZMT of the Manila Times. There was an opening for a disc jockey, and she tried out for the job, competing with well made-up and well-dressed promo girls.

"When I was reading a few lines, somebody was banging the door," Tina remembers. She was asked, "Do you have a cold? Why does your voice sound like that?"'

“This is my natural speaking voice,' I said. Of course it was low and sounded different to them."

She was allowed to continue her audition, and then was stopped again. "Why do you have a British accent?" And she had to explain that the accent was courtesy of her Irish mentor.

Tina got the job and went on to anchor the radio program Times Tower Revue playing classics and Broadway hits. She toned down on the British accent, to Sister Mary Pius' disappointment. The radio stint earned her some measure of fame and the means to pay for her own schooling. It also opened the doors to the rest of the broadcast world.

Andres Monzon brought his daughter to DZMT at 5:00 a.m. for her two-hour radio program. After that, she proceeded to St. Scho or De La Salle, where she had cross-enrolled. "She would come home exhausted and just lie down and fall asleep, wake up briefly to eat and then sleep again," Maritel recalls.

Tina later left DZMT and joined DZHP, where she worked with such broadcast personalities as Bong Lapira and lawyer Jose Mari Velez.

"I don't think she took schooling seriously and neither did I," said Inday. Tina's stint in radio gave them an excuse to cut classes. "Five of us friends would skip classes and go to the radio booth," Inday said. "We'd watch her spinning records."

The late 1960s and early 1970s were years of student unrest in the Philippines, even in an exclusive Catholic girls' school like St. Scho. Journalist Paulynn Sicam, herself a "Kulasa" as the students there are known, recently wrote in a column in the Philippine Star about how, in 1970, "the school was rattled when a group in the graduating college class, fired up by the radicalization of the student movement, questioned the relevance of the 
oral and written comprehensive exams that every Scholastican had to take as a pre-requisite for graduation."

The school ignored the students, who then staged "a Guerrilla Graduation at the Mehan Garden in rites recognized by the Department of Education but not by St. Scho," Paulynn continued. The leader of that group was Marianne (Maan) Hontiveros who became Tina's friend and fellow broadcaster.

That event at Mehan Garden had an impact on Tina although she was not quite as radical. She completed her academic units but refused to push through with her thesis. She admired Hontiveros and company for their guts and told herself she would do as they did, and that having no thesis and no degree did not really matter.

In 1972, then president Ferdinand Marcos declared martial law, shut down the press and took over the big networks. From radio, Tina crossed over to television via the National Media Production Center, and became the weather girl and host of a children's program on the government television channel.

In 1976, she moved to GMA-7, the only commercial station allowed to continue operations during the martial law years. She became the anchor of the evening newscast, a job usually given to older men. Tina was then 26 years old and poised to make TV history.

Her delivery of the news in English in a crisp, clear and deep voice with perfect diction earned Tina a loyal following on the program News at 7 . And because GMA-7 was supposed to be privately owned, viewers tended to regard its news programs and anchors as more credible than those in the government channels.

In those days, there were hardly any news reports in the mainstream broadcast networks of human rights abuses and corruption. But on TV, Tina had come to embody dissent and became a rallying point of anti-Marcos sentiment, or so some people thought.

Viewers would catch her smirking or frowning while reading the news, especially about Marcos. She became famous for those facial expressions, which viewers interpreted as an expression of dissent or opposition.

"Did I consciously do it?" Tina asked herself recently. "No. Sometimes there are words that you can actually savor." She meant no malice, she insisted, and didn't realize people noticed. She believes it's all in the eyes and ears of the beholder, but her viewers still think otherwise.

Although outwardly neutral, Tina's heart is in the right place, her friend Inday Refi-Cascariño said, citing as proof an incident that happened in the early 1980s. Marcos was going on a state visit to the U.S. and Tina, who was doing deskwork and reportorial duties for GMA-7, was assigned to 
cover the trip. Inday, meanwhile, was part of the anti-Marcos movement in the U.S. and organizing a series of protests against Marcos at some of his destinations.

"We were very successful and with good reason," Inday said. "She tipped me off!" Anti-Marcos protesters managed to stage a picket or rally at almost every stop of Marcos' visit because Tina had shared his itinerary with her friend.

Decades later, the two women remember that time as one of the highlights of their friendship and careers. The ending to their collaboration was dramatic. Marcos was at an event in Washington, D.C. Tina was covering him and Inday was with a group of anti-Marcos protesters. Like a scene from a movie, the two friends broke free from the groups they were with-literally opposite sides of the political fence-and ran toward each other and hugged.

Tina Monzon Palma had become a credible news personality even the Marcos government wanted to be associated with. When in late 1985 Marcos called a press conference at which he would announce plans for snap elections, palace officials asked her to be present, even if GMA-7 had already nominated representatives to that event.

Tina covered the EDSA 1986 People Power uprising as GMA-7 news anchor and desk person. But before Marcos fled the country on February 25, 1986, she had already joined other personalities at Channel 4, the government network which by then had been taken over by People Power personalities.

The talent manager Norma Japitana wrote in her diary on February 24, 1986: “...seeing Tina Monzon Palma in Channel 4 was another pleasant development. She is one of the most professional broadcasters, not once betraying partisanship or ill will."

Then president Cory Aquino tapped Tina and lawyer Jose Mari Velez to manage that station, which the Marcos government had called Maharlika Broadcasting System.

Broadcast journalist Ces Drilon was then a young reporter for MBS and talked about those days in a journalism forum. She said, "From producing the most despised, least watched newscast in the country, MBS-4 was transformed to People's Television 4, with Tina Monzon Palma and Jose Mari Velez at the helm. Ratings were off the charts."

"When our network was taken over by the likes of Tina Palma, suddenly we were imbued with credibility," Ces said. 
When Velez decided to leave PTV-4 just a few months later, Tina joined him. The two soon found themselves at GMA-7 as co-anchors of the late evening news, with Tina as senior vice president for news.

After years of repression under Marcos, Filipinos were hungry for information and insights, and Tina thought it was time to put up the network's public affairs programs.

One of those programs was Velez This Week. "It was a ground-breaking talk show format which featured for the first time, three co-hosts, Jose Mari Velez, Perfecto Fernandez and myself," said Melinda Quintos De Jesus, who had been a columnist for the Bulletin Today and editor of Veritas Newsweekly during the Marcos years.

Melinda had also been editor of TV Times, a 1970s magazine that used to feature television shows and personalities, including Tina Palma. The two also became part of an informal group called Women in Media, a band of sisters in the profession, some of whom had written critically of Marcos, and who had come to represent fearless journalism.

Women in Media were known for arranging interviews with officials who spoke to the group off-the-record. The two women became close friends, exchanging notes on work and family. By then Tina was married to businessman Rene Palma with whom she had three sons. Melinda became Tina's choice for female host of Velez This Week.

The format of Velez This Week was Tina's idea, Melinda said, and relied on the appeal of three intelligent and articulate people-two lawyers and a veteran journalist-discussing the latest issue with a featured guest for the week. "It gave the impression that it was as though we had gotten together to talk, not an interview style at all," she added.

Almost every weeknight, GMA-7 would have a public affairs programDong Puno's Viewpoint, Teddy Benigno's Firing Line, Art Borjal's Issues and Answers and Cheche Lazaro's The Probe Team.

On the $20^{\text {th }}$ anniversary of the GMA-7 public affairs division, the network acknowledged Tina's role in it. At one point, it employed 500 people and produced " 16 of the most awarded programs on Philippine television."

Tina Palma's years as GMA-7 senior vice president for news and public affairs was also a time of seismic change for Philippine television. After being shut down by Marcos in 1972, ABS-CBN was back with a vengeance, challenging GMA-7's dominance, targeting the mass audience, making ratings and entertainment the be-all of its programming, and changing the broadcast landscape.

GMA-7, long known for hard news coverage, responded to the ABSCBN challenge by trying to offer more soft news and features. In 1988, the 
network decided to hire young people to complement its retinue of veteran journalists. It announced openings for reporters and at least 150 responded, myself included.

I arrived on the last day of a three-day application period, not expecting to make it. After all, I was then working for a newspaper and showed up only to please my mother, who had been pestering me no end to apply for a job at GMA. Armed with my resume, I joined scores of other hopefuls who seated themselves in the audience gallery of the GMA studio.

Before long, Tina Palma strode into the hall, an imposing presence, planted a microphone stand in the middle of the studio and distributed papers which turned out to be short clippings from the news wires.

She then gave us instructions that I can still hear as clearly as if she had just said them today: "I want you to approach the microphone and read what's written in those papers. You get only one chance to read it. If I don't understand you, you're out."

From those applicants, 20 were eventually selected and asked to write a voice-over script. I was one of the seven who made it through to the end and were finally hired.

That application process told me a few things about Tina Palma. One is that the qualities about a reporter that mattered to her were voice, diction and writing. A pretty face was a bonus, not a requirement. Second is that she is a relatively good judge of ability. From out of that group of 20 that sort of made it to the semi-finals emerged future lawyers and topnotch producers who would embark on thriving careers not just in the country but also abroad.

But the times were calling on GMA-7 to do things differently and follow ABS-CBN's lead. Entertainment took priority. In fact, a collective gasp of shock and consternation dominated the newsroom when management announced that the early evening news program had to give up its timeslot for Inday Badiday's entertainment show Eye-to-Eye.

Tagalog replaced English as the medium of the newscasts, and ABS$\mathrm{CBN}$ led a ratings system that dictated the fate of a TV show. For the sake of higher ratings, news coverage veered toward the sensational and the network wars began. GMA-7, at that time, proved no match to the force that was $A B S-C B N$, with the huge investment it poured into turning the TV newsroom digital. In the meantime, GMA-7 reporters were still using typewriters for their stories.

Crime became the staple of the newscasts. One such story involved Claudio Teehankee Jr., son of a former Supreme Court Justice, who was charged with shooting three young people in Dasmariñas Village in Makati, 
instantly killing Roland Chapman, and seriously wounding Maureen Hultman and Jessi Leino.

Hultman remained in a coma for months. One evening in 1991, as Tina was doing her regular late evening newscast, someone passed her a note saying Hultman had died. Thinking that the news had been verified, she promptly read it on air. The ringing of the phones after the newscast ended told her that what she reported was false.

The error stunned Tina, who had always demanded accuracy and truthfulness from her news teams. She considered it a blow to the network's credibility and, by command responsibility, her fault. She stopped reporting for work and hardly spoke to anyone in the weeks after. Her co-workers learned she had resigned.

The late veteran reporter Jun Bautista who was also Tina's close friend was the source of the news. He was at that time at his usual watering hole at the National Press Club in Manila and would later tell me and other colleagues at the newsroom that he got the information from someone at NPC. Himself a stickler for accuracy, Bote, as he was called, said he contacted the newsroom to have the desk verify reports that Hultman had died.

How Tina ended up with the wrong information was likely a case of something lost in transmission. But to this day, her family and closest friends refuse to discount the possibility that there was more to that incident than it seemed. After all, she was the first female head of the news department, often the target of gossip, intrigues and criticism. She confided to friends that maybe some people wanted her out, and so she resigned and did not put up a fight. An investigation would have been in order, but Tina's departure closed the door on that.

"It was the one big trauma of her career," Melinda said. "It was the first time I saw her really sad and saddened."

"She went on a retreat," Maritel recalls. "She even apologized to the Hultmans. It was a very unforgettable and sad experience."

Many years later, Tina spoke at a management forum about that period in her life. "Since it was my face which was on TV and I was the head of the unit that gathered and delivered the news, I had to be responsible for that error," she said.

"I went into retirement for about a month. And what I learned from that one-month hiatus was that the world did not end with that error," Tina added. "My husband was telling me that I should not have left the job and that I should have told the network owners that it was not my fault. He told me that I would never, ever have a job again as good as what I had." 
I would meet Tina Palma again in early 1992. By then, she was back in circulation as chief operating officer of the newly revived $A B C-5$, which Marcos had also ordered shut in 1972. The new ABC-5 management was on a mission to offer an alternative to the two big networks, producing creative new shows and attempting to inject substance in a TV news milieu that was dominated by blood, gore and showbiz.

I had left GMA and became part of the original news team in the revived ABC-5, now called TV5. The network studios were located in a gleaming new building in what was then faraway Quirino Highway, Barangay Bagbag, Novaliches in Quezon City.

ABC-5 was the home of such shows as Balitang Balita, The Big News, Eezy Dancing and Tropang Trumpo, which would eventually morph into something called Bubble Gang that is still aired on GMA-7 to this day.

Tina's position was several steps higher up the corporate ladder, far removed from the day-to-day concerns of a television newsroom, although the news was under her supervision too and she continued doing the late evening newscast.

In her new role, she dealt with personnel problems and an emerging labor union, but she was also uniquely placed to help chart the future of the network. She remembers negotiating with potential investors on deals that would have helped lift ABC-5 out of its cellar-dwelling position in the ratings game, but the network's conservative owners did not share her eagerness to take the long view.

Tina stayed with Channel 5 for about six years and then went into hibernation again, "cocooning” as she called it. In 1997, ABS-CBN's Gina Lopez invited her to join Bantay Bata and lead the network's public service campaign against child abuse.

I was then with the Philippine Center for Investigative Journalism and all too glad to sit in on a Bantay Bata event, and see her presiding over a meeting of nongovernment organizations working on child rights advocacy.

While doing Bantay Bata, ABS-CBN also asked Tina to take over from Loren Legarda, who won a Senate seat, as co-anchor of The World Tonight with the late Angelo Castro Jr. It is today the country's longest running newscast and at that time was still on Channel 2. But as English language programs slowly disappeared from the free TV networks, The World Tonight found itself moving to the ABS-CBN News Channel (ANC) in 1999.

Tina lived a busy life at ABS-CBN. After Bantay Bata, she became program director of Sagip Kapamilya, going around the country and abroad, delivering relief goods and raising donations for calamity-stricken 
communities. She had a slew of television commitments and at one point even hosted a radio program.

In 2014, she chose to slow down and gave up Sagip Kapamilya, focusing only on her weekly talk show Talkback and the nightly The World Tonight. By then, her husband Rene had been diagnosed with cancer and she opted to spend more time caring for him.

At that time, Cilette Liboro Co, chief operating officer of ANC, asked me to become The World Tonight's supervising producer to support Tina who was its managing editor. I gladly accepted and saw the same Tina Palma I had known before: sharp, disciplined, hardworking and funny.

Never one to keep people waiting, she always arrived at the newsroom well ahead of schedule for taping or airing, brushing up on issues, discussing the news with colleagues, and reading her scripts. She is always tuned in to either AM radio, or television and cable, or online news sites, and monitors what the competition is reporting. She knows who said what about anything during the day and which story is breaking anywhere in the world.

When she presided over story conferences of The World Tonight, she was always several steps ahead of us producers and writers. She never failed to call us out when we reported disaster death toll figures that were several hours old, and often asked us to justify why one story was in a newscast lineup, or why another one was passed up. All this while in a story conference peppered with laughter, or while sharing Amber pancit or food packs from one of the Jollibee branches her family owned, or while giving me a share of the dinner that she packed from home every day.

Tina hasn't experienced any fiascos like the one that forced her to quit GMA-7 in 1991, but the newsroom and its inhabitants make mistakes in the rush to feed the 24/7 news cycle. We remind ourselves to make the newscast as error-free as possible. But mistakes do slip through the cracks, and Tina has accepted apologies from us producers and reporters, and has given them herself.

"Sorry, Ma'am!" I remember telling her after a script identified a government official as a "she" when it should have been a "he." "It's ok," she simply replied.

For her part, she once said that a brigadier general with whom she was about to do a phone-patch interview had retired. We and her producers said he hadn't. She insisted and we let her have her way. On air, she introduced him as a retired official, only to find herself corrected by the general himself. Reminded of the error during the commercial break, her response was: "Tao lang po (I'm only human)."

Tina is down-to-earth and could be as funny as she is serious. She calls friends "pare," regardless of age or gender, is always warm toward former 
colleagues, and never hesitates to get together with friends whenever her health and schedule permit it.

Over the years, I would run into Tina at journalism events organized by the Center for Media Freedom and Responsibility where she leads the Board of Trustees and where her friend Melinda Quintos de Jesus is executive director. That involvement speaks about Tina's commitment to press freedom and excellent journalism.

But mostly, talks with Tina are memorable for the stories and insights she shares. For someone who has been in the broadcast industry for close to half a century and in the news business for four decades, she has seen all sorts of newsmakers and news movers, and all of them might just find themselves in a memoir Tina says she will write one day.

\section{References}

20 years of GMA Public Affairs: The humble beginnings. (2007, October 28), GMA news online Retrieved from http://www.gmanetwork.com/news/news/nation/63107/20-years-of-gma-public-affairs-thehumble-beginnings/story/.

Japitana, N. (2011, Feb. 25). Four days that changed our lives. Retrieved from http://www.philstar.com/ entertainment/660466/four-days-changed-our-lives.

Monzon Palma, T. (2003, Feb. 3). In trying to beat the competition, we made a mistake. Retrieved from http://archives.newsbreak-knowledge.ph/2003/02/03/in-trying-to-beat-the-competition-wemade-a-mistake/.

Oreña-Drilon, C. (2008, Oct. 25). No better job than journalism. Retrieved from http://news.abs-cbn.com/ features/10/24/08/ces-drilon-no-better-job-journalism.

Sicam, P. (2016, Nov. 26). Heart and mind: Kulasa. Retrieved from http://www.philstar.com/modernliving/2016/11/26/1647515/kulasa?nomobile=1.

LUZ RIMBAN obtained her BA in Journalism from the University of the Philippines, and her MA in Journalism from the Ateneo de Manila University. She worked with Tina Monzon Palma at GMA-7, ABC-5 and the ABS-CBN News Channel. 


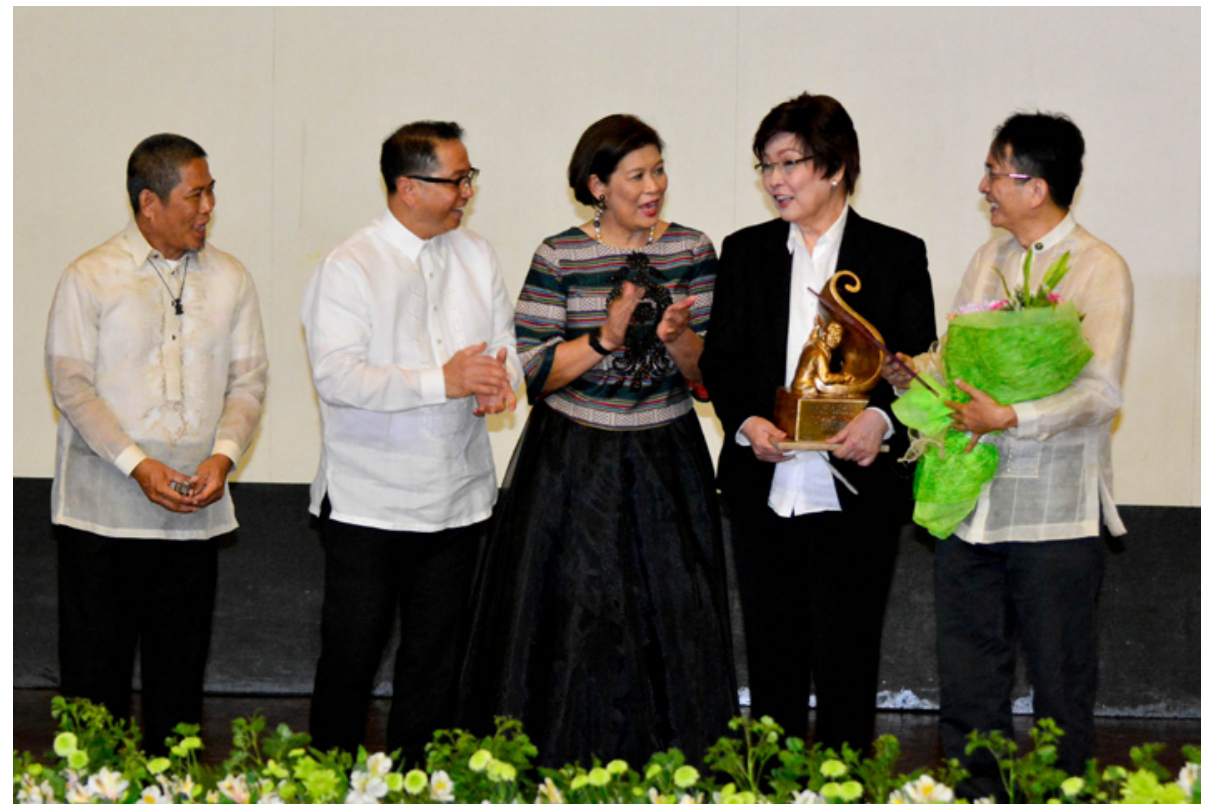

Ms.Tina Monzon-Palma accepts the U.P.Gawad Plaridel (2017) Award. From left:Professor Eulalio III Guieb, U.P. President Danilo Concepcion, CMC Dean Elena E. Pernia, Ms. Tina Palma, and Diliman Chancellor Michael Tan. (Photo courtesy of Alex NP Tamayo and the Office of Extension and External Relations)

\section{Gawad Plaridel 2017 Prepared Speech* Tina Monzon-Palma}

Opening: Light and funny retelling of the transmitter story during the Cory coups.

I'm telling you this story because when I look back, I can tell you I was being reckless and silly, not resourceful and brave.

I didn't think anything would come of that stunt I pulled, but I knew I had to do something.

We try to pretend we are brave and somehow that little piece of courage sees us through. We keep our wits and harness all the smarts we've learned through the years and we raise our chin.

You've all seen that overused, trite, cliché drawing of the candle in the dark, right? That symbol came to life from that little piece of courage we all try to keep alive. One person carried the strongest flame. One friend was unwavering, clear headed. She was Letty Jimenez Magsanoc.

A month ago,I read with sadness that the Prietos sold a majority stake in the newspaper that started as a "mosquito press" to Ramon Ang. 
I wonder how my dear friend, Letty would have reacted.

I wonder if it would have happened at all if she was still at the helm. Sadly, these are not questions I can ever answer. Thinking about Letty led my mind to wander back to the early year of the 1980's, when media played a key role in awakening a nation from two decades of slumber.

Looking back at Martial Law, people talk about the First Quarter Storm and the events leading up to the February Revolution.

But few talk about the years in between, the hard years, the darkest hours, the years, when all hope seemed lost and no silver lining was in sight.

These were the years when almost everything you watched, heard or read were a tepid, timid and whitewashed version of reality.

These were the years when people lived in fear of the knock on the door in the night, which often ended with people dying or going missing.

But wait, this generation IS living through an version of that time.PREEDSA.2.0

I'm talking about the crony press, but you call it fake news.

In many ways those years are uncannily similar today.

Except that everything is on steroids.

During those years, everything was placid above ground but there was groundswell underneath. How fast will this generation's volcano explode? Everything happens ten times faster. The fires of defiance, disobedience and struggle were lit by a lifestyle magazine called Mr. and Ms. It was a voice in the wilderness. In a way we're back in the wilderness - when before we had censorship, now we are in a wasteland of hate and intolerance.

Why am I telling you this? Because my main take away is it is darkest before the dawn.

Have our standards about public officials and the media moved from the original mark. Is it because of fear, conditioning or because we've been desensitized.

1. Offensive language is the new normal from the highest official of the land

2. Teleprompters are a thing of the past with freewheeling speeches even on SONA

3. Creative interpretation.. new name for spindoctoring

4. 30 people are killed in a night and it's just a statistic.

Historians point to a "revolt "against liberalism worldwide and the rise of authoritarianism. President Donald Trump, Vladimir Putin, Nicolas Maduron, Recep Tayyip Erdogan and Rodrigo Duterte.

As journalist, what role do we play in this new wave of authoritarianism and hate speech? [emphasis by author] 
Do we still matter-as the role of gatekeeper shifts from content producers to curators like Facebook?

Before the advent of fake news, many were saying, the journalist will be replaced by the citizen journalists.

But as truth becomes blurred, our role once again becomes clear-to investigate, cut through the white noise, present the situation as clearly as possible and ask the hard questions.

There was a time when news programs on TV and radio were the number one sources of news.

That has dramatically changed. Increasingly, these programs share the influence over audiences with the internet.

Ironically, as the internet democratized opinion dissemination, media lost its halo.

Fake news and the proponents of the campaign line "media is bias" (without the ED)eroded trust in the media.

But our trade depends on trust. In the absence of truth, you have no choice but to believe the person in power. [emphasis by author]

How do we remain relevant in an age when truth itself seems to be under assault?

There is only one answer, my friends. The media cannot be timid.

Media need not be timid if it sticks to good journalism. [emphasis by author]

Its best weapon against lies is to be transparent, thorough and provocative.

When mainstream media descends into unobtrusiveness, it does its audience a disservice.

When media masters the art of camouflage, the people will forget.

When media becomes muted, we let the underlying message behind the trolls and the propaganda machines dominate the discourse.

What is this underlying message? Edward R Murrow named that evil a long time ago.

That is when people equate dissent with disloyalty.

To every Filipino,

Wala tayong karapatang manghiya, manindak at magpalaganap ng pagkamuhi.

May karapatan tayong maging-weird,maging kakaiba at magkamali.

May karapatan tayong tumuligsa magtanong at magpahayag.

To my friends in the media now, this challenge is upon you. [emphasis by author] 
30 years ago media answered that call. Now it is your turn. [emphasis by author]

\#HuwagMatakot. It is darkest before the dawn.

\section{Note}

* Actual speech of Ms. Tina Monzon-Palma can be viewed at https://www.youtube.com/ watch?v=QmtoVqIS680. 